\title{
MIROSŁAW GOGOLIK \\ Uczynki miłosierdzia względem ciała i względem ducha w posłudze katechetycznej
}

Papież Franciszek w bulli Misericordiae vultus, ogłaszającej nadzwyczajny jubileusz miłosierdzia, pośród wielu postulatów i zaleceń, zwraca się do wiernych Kościoła z gorącym życzeniem, aby chrześcijanie przemyśleli podczas Jubileuszu uczynki miłosierdzia względem ciała $i$ względem ducha ${ }^{l}$. Pochylenie się w tym szczególnym czasie nad uczynkami miłosierdzia, zgodnie z intencją Papieża stanie się sposobem na obudzenie naszego sumienia, często uśpionego, a także pozwoli na coraz głębsze wejście w serce Ewangelii, aby poznać, czy żyjemy jak Jego uczniowie, czy też nie ${ }^{2}$.

Podejmując to życzenie Franciszka warto przemyśleć i odkryć na nowo uczynki miłosierdzia względem ciała i względem ducha w przestrzeni katechetycznej, ich miejsce w przepowiadaniu katechetycznym i formy czynnego wypełniania tychże uczynków miłosierdzia, podejmowane i inspirowane przez szkolne lekcje religii oraz katechezę parafialną. W tym celu analizie zostaną poddane współcześnie obowiązujące dokumenty katechetyczne, materiały programowe katechezy w Polsce oraz wybrane pomoce do nauczania religii, mianowicie podręczniki, karty pracy, itp. Wykorzystywane na kolejnych etapach edukacyjnych.

\section{Wychowanie moralne w katechezie}

Jednym z podstawowych zadań katechezy, określonych przez Kościól, obok rozwijania poznania wiary, wychowania liturgicznego, nauczania modlitwy,

Mirosław G O G O L I K, ks. dr hab., adiunkt w Zakładzie Katechetyki i Pedagogiki Chrześcijańskiej Wydziału Teologicznego UAM w Poznaniu, e-mail: mirgo@amu.edu.pl

${ }^{1}$ F r a n c i s z e k: Bulla Misericordiae vultus. Rzym 2015 nr 15.

${ }^{2}$ Por. Tamże. 
wychowania do życia wspólnotowego i do misji, jest formacja moralna dzieci i młodzieży ${ }^{3}$. Formacja moralna dzieci i młodzieży wpisuje się w sposób jednoznaczny w cały proces wychowania i kształtowania młodego pokolenia, które dokonuje się w rodzinie i przez rodziców, wspartych służebną rolą między innymi Państwa, szkoły i wspólnoty Kościoła. W Deklaracji o wychowaniu chrześcijańskim Vaticanum II, czytamy, iż Kościół wypełniając nakaz otrzymany do Boskiego swego Założyciela powinien troszczyć się o całe życie ludzkie, również o życie ziemskie, o ile ono taczy się z powołaniem niebiańskim - przeto ma on też swój udziat w rozwoju i postepie wychowania ${ }^{4}$. Wychowanie i rozwój moralny uczniów, wpisany jest zatem także w założenia współczesnej edukacji, dążącej do tego, aby uczniowie stawali się coraz bardziej samodzielni $w$ dązeniu do dobra w jego wymiarze indywidualnym i społecznym, godzac umiejętnie dążenie do dobra wlasnego z dobrem innych, odpowiedzialność za siebie i odpowiedzialność za innych ${ }^{5}$. Integralny rozwój człowieka obejmuje całość życia ludzkiego w wymiarze cielesno-duchowym, a zwłaszcza wychowanie: ekologiczne, estetyczne, fizyczne, moralne, patriotyczne, seksualne, społeczne, techniczne, umysłowe. Zadaniem fundamentalnym wychowania moralnego jest rozbudzenie $i$ ksztaltowanie u dzieci i młodzieży przekonań i postaw zgodnych $z$ uznawanymi $w$ danym społeczeństwie normami i obyczajami ${ }^{6}$. Możemy zatem uznać, iż wychowanie moralne dokonuje się zawsze w oparciu o konkretny zakres norm i treści, kultury i środowiska w którym żyje człowiek, dlatego $D y$ rektorium ogólne o katechizacji formację moralną wiąże ściśle z zadaniem wprowadzenia wierzących w pełnię życia chrześcijańskiego, która charakteryzuje się:

- postawą nawrócenia do Jezusa Chrystusa,

- drogą przekształcenia wewnętrznego,

\footnotetext{
${ }^{3}$ Por. Kongregacja ds. Duchowieństwa: Dyrektorium Ogólne o Katechizacji. Tekst pol. Poznań1998 nr 85-86 [dalej: DOK].

${ }^{4}$ Deklaracja o wychowaniu chrześcijańskim. Wstęp. w: Sobór Watykański II. Konstytucje, Dekrety, Deklaracje. Tekst pol. Poznań1967.

${ }^{5}$ Ministerstwo Edukacji Narodowej: O reformie programowej. I etap edukacyjny - kształcenie zintegrowane. Biblioteczka Reformy 7. Warszawa 1999 s. 12. W świetle współczesnej myśli pedagogicznej wychowanie to ogół czynności związanych z oddziaływaniem środowiska przyrodniczego i społecznego na człowieka, kształtujących jego osobowość i trwających przez całe życie. (...) Ogólnie wychowanie można podzielić na: NATURALNE - oddziaływanie środowiska, w którym jednostka żyje i funkcjonuje, tj. rodzina, środowisko lokalne, kontakty interpersonalne, a także obyczaje i religia; INSTYTUCJONALNE - planowane oddziaływanie instytucji, np. szkoły; oraz SAMOWYCHOWANIE. Zob. Wychowanie. w: Cz. Ku p i s i e w i c z, M. K u p i s i e w i c z: Stownik pedagogiczny. WARSZAWA 2009 s. 193.

${ }^{6}$ Wychowanie, w: Cz. Ku p i s i e w i c z, M. K u p i s i e w i c z: Stownik pedagogiczny. Warszawa 2009 s. 193.
} 
- kształtowaniem swojego życia w duchu naśladowania Jezusa Chrystusa, przez poznanie norm ewangelicznych zawartych $w$ dekalogu i kazaniu na Górze,

- dawaniem świadectwa moralnego w życiu społecznym ${ }^{7}$.

Ukazany proces wychowania moralnego dokonuje się w dwóch wymiarach, wertykalnym - jako relacji człowieka do Boga oraz horyzontalnym - polegającym na odkrywaniu własnej relacji do drugiej osoby, swojego miejsca w społeczeństwie, przestrzeganiu norm i obowiązków, nienaruszalnego prawa Bożego oraz rozwoju chrześcijańskiej doskonałości ${ }^{8}$. Na tej podstawie możemy wyróżnić następujące obszary przedmiotowe wychowania moralnego w katechezie: wychowanie do wartości i dojrzałej osobowości, nauka normy moralnej i kształtowanie sumienia, kształtowanie postaw moralnych i relacji międzyludzkich.

Niewątpliwie uczynki miłosierdzia względem ciała i względem ducha, wpisują się $\mathrm{w}$ podane powyżej obszary formacji moralnej w nauczaniu religii. Życzenie zatem papieża Franciszka, aby przemyśleć i odkryć na nowo uczynki miłosierdzia, staje się okazją do głębszego spojrzenia podczas katechezy na tę, jakże ważną, normę chrześcijańskiej moralności. Pozwoli to również kształtować dojrzałą osobowość wychowanków poprzez obudzenie i formację sumienia oraz ukazywanie powołania chrześcijańskiego i wynikających z niego zobowiązań - zgodnie ze następującym wskazaniem Dyrektorium ogólnego o katechizacji - formacja moralna nie tylko przekazuje treść moralności chrześcijańskiej, lecz również czynnie kultywuje postawy ewangeliczne i wartości chrześcijańskie ${ }^{9}$. Pełnia skuteczności posługi katechetycznej - jak naucza Kościół - dokonuje się przez kształtowanie właściwych postaw moralnych oraz relacji międzyludzkich, budowanych na fundamencie nauki chrześcijańskiej i cnotach ewangelicznych, stanowiących chrześcijańską moralność społeczną - będącą wymaganiem i konsekwencją radykalnego wyzwolenia dokonanego przez Chrystusa, stanowiącą chrześcijańską praktykę wypełnienia wielkiego przykazania miłości $^{10}$. Papież Franciszek zachęca wiernych Kościoła, a zatem także katechizowanych, aby doświadczyli w roku świętym otwarcia serca i praktykowali uczynki miłosierne: Nasze ręce niech ścisna ich ręce, przyciagnijmy ich do siebie, aby poczuli ciepło naszej obecności, przyjaźni i braterstwa. Niech ich krzyk stanie się naszym, tak byśmy razem złamali barierę obojętnościll.

Podejmując zachętę Ojca świętego do przemyślenia i odkrycia na nowo uczynków miłosierdzia, przeanalizujmy aktualnie obowiązujące dokumenty

\footnotetext{
${ }^{7}$ Por. DOK 85.

${ }^{8}$ Por. J. S z p e t: Dydaktyka katechezy. Poznań 1999 s. 37.

${ }^{9}$ DOK 87.

${ }^{10}$ Por. DOK 104, 108.

${ }^{11} \mathrm{Fr}$ a n c i s z e k: Bulla Misericordiae vultus, dz. cyt. nr 15.
} 
programowe katechezy w Polsce oraz podręczniki do nauki religii, ukazując miejsce uczynków miłosierdzia w katechezie. Dla większej przejrzystości prezentowanego materiału, posłużymy się podziałem na wskazane powyżej trzy obszary wychowania moralnego, czyli wychowanie do wartości i dojrzałej osobowości, naukę normy moralnej i kształtowanie sumienia oraz kształtowanie postaw moralnych i relacji międzyludzkich.

\section{Uczynki milosierdzia w Podstawie programowej katechezy Kościola katolickiego w Polsce}

Programowanie procesu katechetycznego we wspólnocie Kościoła obejmuje przede wszystkim tworzenie ram, które umożliwiają w różnorodny sposób prowadzenie posługi katechetycznej, przy zachowaniu jednolitości celów katechetycznych, zadań i zakresu integralnego treści nauki religii. Ramy programowe katechezy w Polsce zostały określone w Podstawie programowej katechezy Kościoła katolickiego w Polsce ${ }^{I 2}$, zatwierdzonej przez Konferencję Episkopatu Polski dnia 8 marca 2010 roku i wprowadzonej uchwałą Komisji Wychowania Katolickiego z dnia 9 czerwca 2010 roku w sprawie obowiązywania Podstawy programowej katechezy Kościoła katolickiego w Polsce ${ }^{13}$ oraz w Programie nauczania religii rzymskokatolickiej $w$ przedszkolach i szkołach ${ }^{14}$, wydanym przez tę komisję. Podstawa programowa katechezy stanowi fundament dla tworzonych programów nauczania religii i obowiązujących podręczników. Skupimy się zatem na analizie tegoż dokumentu, w celu ukazania omawianego zagadnienia na poszczególnych etapach katechizacji.

Planowanie dydaktyczne katechezy w Polsce opiera się na ogólnych założeniach i obowiązującej we współczesnej edukacji terminologii, mianowicie wprowadzono pojęcie celów katechetycznych, równoznacznych z wymaganiami ogólnymi, które należy osiągnąć w ramach nauczania religii na danym etapie edukacyjnym oraz pod pojęciem treści - wymagań szczegółowych osiągnięć ucznia. Pojęcie wymagań szczegółowych zawiera w sobie katalog wiadomości oraz oczekiwanych umiejętności, jakie uczeń winien przyswoić i posiąść na danym etapie edukacyjnym ${ }^{15}$. Tak skonstruowane planowanie dydaktyczne pomaga nauczycielowi religii nie tylko weryfikować przyswajalność treści i wiedzy religijnej, ale także motywować do wprowadzania zdobytej wiedzy

${ }^{12}$ Konferencja Episkopatu Polski: Podstawa programowa katechezy Kościoła katolickiego w Polsce. Kraków 2010.

${ }^{13}$ Por. Uchwata Komisji Wychowania Katolickiego Konferencji Episkopatu Polski z dnia 9 czerwca 2010 r. w sprawie obowiazywania „Podstawy programowej katechezy Kościoła katolickiego w Polsce”. , Katecheta” 9: 2010 s. 79.

${ }^{14}$ Komisja Wychowania Katolickiego Konferencji Episkopatu Polski: Program nauczania religii rzymskokatolickiej w przedszkolach i szkołach. Kraków 2010.

${ }^{15}$ Konferencja Episkopatu Polski: Podstawa programowa katechezy..., dz. cyt. s. 13. 
w praktykę życia i doświadczenia religijnego. Zasada ta sprawdza się również w odniesieniu do omawianego zagadnienia, weryfikując nie tylko znajomość normy moralnej, wyrażonej przez Jezusa Chrystusa w uczynkach miłosierdzia względem ciała i względem ducha, ale także praktyczne wypełnienie poznanej normy w życiu poprzez właściwą ocenę ukształtowanego sumienia, ochronę wartości miłosierdzia i praktykowanie miłosierdzia w relacjach międzyludzkich.

Analiza planowania dydaktycznego katechezy w Polsce, oparta na obowiązującej Podstawie programowej, potwierdza umieszczenie bezpośrednio lub pośrednio na wszystkich etapach edukacji religijnej zagadnień dotyczących wychowania moralnego w zakresie uczynków miłosierdzia względem ciała i względem ducha. Autorzy Podstawy programowej proponują podjęcie tegoż zagadnienia przy omawianiu tematów związanych z wychowaniem do wartości, opartych o chrześcijańską normę moralną i wynikających z wiary konsekwencji dla życia chrześcijanina. Proponowane treści dotyczące chrześcijańskich uczynków miłosierdzia, znajdujemy najpierw w obszarze wychowania do wartości, gdzie zwraca się uwagę na kształtowanie w katechizowanych postaw dojrzałego człowieczeństwa, z uwzględnieniem chrześcijańskiego świata wartości. Szczegółowe treści w tym obszarze pracy edukacyjnej, przedstawia poniższe zestawienie tabelaryczne, opracowane na podstawie analizowanego dokumentu.

\begin{tabular}{|c|c|c|}
\hline \multirow{2}{*}{$\begin{array}{l}\text { Cele katechetyczne - } \\
\text { wymagania ogólne }\end{array}$} & \multicolumn{2}{|c|}{ Treści - wymagania szczegółowe } \\
\hline & Wiadomości & Umiejętności ucznia \\
\hline $\begin{array}{l}\text { Przedszkole } \\
\text { Dziecko: } \\
\text { - buduje podstawy systemu } \\
\text { wartości, }\end{array}$ & $\begin{array}{l}\text { - Ukazać związek z Bogiem } \\
\text { zapoczątkowany na chrzcie } \\
\text { świętym i wynikające z tego } \\
\text { konsekwencje. }\end{array}$ & $\begin{array}{l}\text { - rozróżnia przykłady zachowania } \\
\text { godnego i niegodnego dziecka } \\
\text { Bożego, ucznia Jezusa, } \\
\text { - podaje przykłady dobrego } \\
\text { zachowania dziecka Bożego, }\end{array}$ \\
\hline $\begin{array}{l}\text { Szkoła Podstawowa, } \\
\text { klasy I - III } \\
\text { Uczeń: } \\
\text { - pogłębia motywację wia- } \\
\text { ry w przestrzeganiu Dekalogu. }\end{array}$ & $\begin{array}{l}\text { - Wiara źródłem ludzkiej życz- } \\
\text { liwości, pogody ducha, radości. } \\
\text { - Nauczanie Jezusa w przypo- } \\
\text { wieściach. } \\
\text { - Pomoc chorym i cierpiącym. } \\
\text { - Postaci biblijne przykładem } \\
\text { życia wiary. Przykłady życia } \\
\text { według Ewangelii. }\end{array}$ & $\begin{array}{l}\text { - omawia wybrane przypowieści } \\
\text { Jezusa, } \\
\text { - podaje przykłady niesienia } \\
\text { pomocy innym, } \\
\text { - wskazuje, w czym może naśla- } \\
\text { dować postaci biblijne i świętych. }\end{array}$ \\
\hline $\begin{array}{l}\text { Klasy IV-VI } \\
\text { Uczeń: } \\
\text { - rozpoznaje swoje podstawowe } \\
\text { wartości i dokonuje właściwej } \\
\text { ich hierarchizacji, } \\
\text { - wyraża opinie i wartościuje } \\
\text { zjawiska społeczno-religijne na } \\
\text { poziomie społeczności szkolnej } \\
\text { i społeczności lokalnej. }\end{array}$ & $\begin{array}{l}\text { - Wartość życia i zdrowia oraz } \\
\text { ich zagrożenia. } \\
\text { - Trudne sytuacje życiowe: } \\
\text { choroba, śmierć. }\end{array}$ & $\begin{array}{l}\text { - wskazuje chrześcijańskie mo- } \\
\text { tywy wyborów w codziennym } \\
\text { życiu, } \\
\text { - przejawia refleksyjną postawę } \\
\text { wobec różnych sytuacji życio- } \\
\text { wych zobowiązań moralnych, }\end{array}$ \\
\hline
\end{tabular}




\begin{tabular}{|c|c|c|}
\hline $\begin{array}{l}\text { Gimnazjum } \\
\text { Uczeń: } \\
\text { - w oparciu o posiadaną wiedzę } \\
\text { wypracowuje względnie stałe } \\
\text { zachowania, reakcje poznawcze, } \\
\text { emocjonalnie umotywowane } \\
\text { wartościami najwyższymi, } \\
\text { odnosząc je zwłaszcza do miłości } \\
\text { Boga, Kościoła, Ojczyzny i } \\
\text { rodziny, } \\
\text { - osiąga pewną integrację życia } \\
\text { psychicznego, fizycznego, } \\
\text { uczuciowego, intelektualnego } \\
\text { i religijnego. }\end{array}$ & $\begin{array}{l}\text { - Podstawowe pojęcia etyczne: } \\
\text { wartości i ich hierarchia. } \\
\text { - Przykazania Dekalogu: warto- } \\
\text { ści, których bronią przykazania. } \\
\text { - Pojęcie miłości i sposoby jej } \\
\text { przeżywania. } \\
\text { - Świętość w rozmaitych for- } \\
\text { mach życia. } \\
\text { - Osiem błogosławieństw jako } \\
\text { podstawa życia w łasce Bożej. }\end{array}$ & $\begin{array}{l}\text { - charakteryzuje obowiązki } \\
\text { wynikające z poszczególnych } \\
\text { przykazań Bożych, } \\
\text { - interpretuje rozumienie pojęcia } \\
\text { prawdziwej miłości w różnych } \\
\text { aspektach życia ludzkiego, }\end{array}$ \\
\hline $\begin{array}{l}\text { Szkoły ponadgimnazjalne } \\
\quad \text { Kształtowanie tożsamości } \\
\text { katechizowanej młodzieży } \\
\text { dokonuje się poprzez korelację } \\
\text { treści i zdobytej dotychczas } \\
\text { wiedzy w następujących obsza- } \\
\text { rach: } \\
\text { - analiza tekstów i interpretacja } \\
\text { tekstów o charakterze religijnym, } \\
\text { - socjalizacja kościelna, } \\
\text { - odkrywanie powołania chrze- } \\
\text { ścijańskiego, } \\
\text { - tworzenie wypowiedzi, obser- } \\
\text { wacje i doświadczenia. }\end{array}$ & $\begin{array}{l}\text { - Osoba i jej godność, wolność } \\
\text { osoby. } \\
\text { - Wartość prawdy w życiu osoby } \\
\text { i społeczności, w której dokonu- } \\
\text { je się jej rozwój. } \\
\text { - Rodzaje powołań w Kościele } \\
\text { i sposoby ich realizacji. Realiza- } \\
\text { cja powołania w Kościele } \\
\text { lokalnym. }\end{array}$ & $\begin{array}{l}\text { - odczytuje człowieczeństwo } \\
\text { jako dar zadany człowiekowi, } \\
\text { - charakteryzuje wybrane drogi } \\
\text { powołania chrześcijańskiego, } \\
\text { - wskazuje praktyczne możli- } \\
\text { wości nabywania cnót, } \\
\text { - hierarchizuje nabywane przez } \\
\text { chrześcijanina cnoty, ze szcze- } \\
\text { gólnym uwzględnieniem miło- } \\
\text { ści, } \\
\text { - ocenia rozumienie godności } \\
\text { człowieka } w \text { różnych systemach }^{\text {etycznych }}{ }^{16} \text {. }\end{array}$ \\
\hline
\end{tabular}

Kolejnym obszarem posługi katechetycznej, który obejmuje zagadnienie formacji moralnej w zakresie uczynków miłosierdzia jest omawianie w ramach katechezy normy moralnej i kształtowanie sumienia uczniów. Podstawa programowa na poszczególnych etapach katechizacji, proponuje nauczanie dzieci i młodzieży normy moralnej zawartej w treści przykazania miłości Boga i bliźniego, Dekalogu, Ośmiu Błogosławieństw i ewangelicznych wskazań Jezusa Chrystusa, co prezentuje poniższe zestawienie.

${ }^{16}$ Por. Konferencja Episkopatu Polski: Podstawa programowa katechezy..., dz. cyt. s. $17-78$. 


\begin{tabular}{|c|c|c|}
\hline \multirow{2}{*}{$\begin{array}{l}\text { Cele katechetyczne - } \\
\text { wymagania ogólne }\end{array}$} & \multicolumn{2}{|c|}{ Treści - wymagania szczegółowe } \\
\hline & Wiadomości & Umiejętności ucznia \\
\hline $\begin{array}{l}\text { Przedszkole } \\
\quad \text { Dziecko: } \\
\text { - poznaje chrześcijańskie pojęcia } \\
\text { dobra i zła, } \\
\text { - odkrywa znaczenie przykaza- } \\
\text { nia miłości Boga i bliźniego oraz } \\
\text { jego konsekwencje. }\end{array}$ & $\begin{array}{l}\text { - Przykazanie miłości Boga } \\
\text { i bliźniego. }\end{array}$ & $\begin{array}{l}\text { - wyjaśnia swoimi słowami, co } \\
\text { znaczy kochać Boga i bliźnie- } \\
\text { go, } \\
\text { - rozróżnia przykłady zacho- } \\
\text { wania godnego i niegodnego } \\
\text { dziecka Bożego, ucznia Jezusa, } \\
\text { - przestrzega zasad obowiązu- } \\
\text { jących dziecko Boże i ucznia } \\
\text { Jezusa }\end{array}$ \\
\hline $\begin{array}{l}\text { Szkoła Podstawowa, } \\
\text { klasy I-III } \\
\text { Uczeń: } \\
\text { - pogłębia rozumienie Przykazań } \\
\text { Bożych. }\end{array}$ & $\begin{array}{l}\text { - Pojęcie sumienia. Dekalog } \\
\text { wyrazem troskliwej miłości } \\
\text { Boga wobec ludzi. Treść i } \\
\text { znaczenie poszczególnych } \\
\text { przykazań Dekalogu. } \\
\text { - Nauczanie Jezusa w przypo- } \\
\text { wieściach. Pomoc chorym } \\
\text { i cierpiącym. } \\
\text { - Postaci biblijne przykładem } \\
\text { życia wiary. Przykłady życia } \\
\text { według Ewangelii. }\end{array}$ & $\begin{array}{l}\text { - omawia wybrane przypowie- } \\
\text { ści Jezusa, } \\
\text { - opowiada o znaczeniu sumie- } \\
\text { nia, } \\
\text { - wyjaśnia, jakie postawy } \\
\text { sprzeciwiają się Bożym przy- } \\
\text { kazaniom, } \\
\text { - wskazuje, jak w codziennym } \\
\text { życiu należy zachowywać } \\
\text { przykazania Boże, } \\
\text { - omawia normy kolejnych } \\
\text { przykazań Dekalogu }\end{array}$ \\
\hline $\begin{array}{l}\text { Klasy IV-VI } \\
\quad \text { Uczeń: } \\
\text { - prezentuje refleksyjną postawę } \\
\text { wobec człowieka, jego natury, } \\
\text { powinności moralnych oraz } \\
\text { wobec różnych sytuacji życio- } \\
\text { wych. }\end{array}$ & $\begin{array}{l}\text { - Dekalog i Błogosławieństwa } \\
\text { wyrazem troski Boga o szczęście } \\
\text { człowieka. } \\
\text { - Świętowanie i spędzanie } \\
\text { wolnego czasu po chrześcijań- } \\
\text { sku. }\end{array}$ & $\begin{array}{l}\text { - wskazuje różnicę między } \\
\text { dobrem i złem w podstawo- } \\
\text { wych sytuacjach moralnych, } \\
\text { - dostrzega konsekwencje } \\
\text { dobra i zła, } \\
\text { - wskazuje, jak zastosować } \\
\text { wskazania prawa Bożego } \\
\text { w konkretnych sytuacjach } \\
\text { życiowych, } \\
\text { - rozumie, co znaczy być } \\
\text { odpowiedzialnym, } \\
\text { - wskazuje, jak pracować nad } \\
\text { rozwojem sumienia chrześci- } \\
\text { jańskiego, }\end{array}$ \\
\hline $\begin{array}{l}\text { Gimnazjum } \\
\text { Uczeń: } \\
\text { - nabywa umiejętność oceny } \\
\text { swego postępowania moralnego, } \\
\text { konfrontując je z nauką Bożą. }\end{array}$ & $\begin{array}{l}\text { - Podstawowe pojęcia etyczne: } \\
\text { powinność moralna, sumienie, } \\
\text { prawo naturalne, prawo Boże. } \\
\text { - Przykazania Dekalogu: warto- } \\
\text { ści, których bronią przykazania. } \\
\text { Wykroczenia przeciw przykaza- } \\
\text { niom i ich konsekwencje. } \\
\text { - Pojęcie miłości i sposoby jej } \\
\text { przeżywania. } \\
\text { - Osiem błogosławieństw jako } \\
\text { podstawa życia w łasce Bożej. }\end{array}$ & $\begin{array}{l}\text { - charakteryzuje obowiązki } \\
\text { wynikające z poszczególnych } \\
\text { przykazań Bożych, } \\
\text { - opisuje wykroczenia prze- } \\
\text { ciwko poszczególnym przyka- } \\
\text { zaniom Bożym, } \\
\text { - interpretuje rozumienie } \\
\text { pojęcia prawdziwej miłości } \\
\text { w różnych aspektach życia } \\
\text { ludzkiego, } \\
\text { - uzasadnia koncepcję szczę- } \\
\text { ścia zawartą w Ośmiu Błogo- } \\
\text { sławieństwach, } \\
\text { - ilustruje właściwe zachowa- } \\
\text { nia dzieci względem rodziców, }\end{array}$ \\
\hline $\begin{array}{l}\text { Szkoły ponadgimnazjalne } \\
\text { Kształtowanie tożsamości } \\
\text { katechizowanej młodzieży } \\
\text { dokonuje się poprzez korelację }\end{array}$ & $\begin{array}{l}\text { - Osoba i jej godność, wolność } \\
\text { osoby. } \\
\text { - Powołanie chrześcijańskie. } \\
\text { - Teologiczne rozróżnienie }\end{array}$ & $\begin{array}{l}\text { - odczytuje człowieczeństwo } \\
\text { jako dar zadany człowiekowi, } \\
\text { - współczesne nurty myślo- } \\
\text { we, związane z negacją }\end{array}$ \\
\hline
\end{tabular}




\begin{tabular}{|l|l|l|}
\hline $\begin{array}{l}\text { treści i zdobytej dotychczas } \\
\text { wiedzy. }\end{array}$ & grzechów. & prawdy, \\
& - Moralność i składowe czynu & - wskazuje źródła moralności \\
& moralnego. & (prawo naturalne, prawo \\
& - Sumienie, jego rodzaje oraz & Boże), \\
& zasady formacji. & - określa specyfikę chrześci- \\
& jańskiego rozumienia moral- \\
& ności, \\
& - charakteryzuje kryteria \\
& czynu moralnego (przedmiot, \\
& & cel, okoliczności) ${ }^{17}$. \\
\hline
\end{tabular}

Niewątpliwie ważnym elementem w pracy katechetycznej jest nie tylko przekazanie wiedzy religijnej w postaci wykładu normy moralnej, ale przede wszystkim wychowywanie i kształtowanie postaw moralnych, ujawniających się w codziennym doświadczeniu życia, a zwłaszcza w relacjach międzyludzkich. Motywacja do wypełniania w codziennym życiu, w sposób czynny chrześcijańskich dzieł miłosierdzia staje się jednym z kluczowych celów katechezy, która prowadzi do naśladowania Jezusa Chrystusa i wypełniania ewangelicznych wskazać przez współczesnych uczniów. W obszarze kształtowania postaw Podstawa programowa katechezy proponuje w prowadzenie zagadnień dzieł i uczynków miłosierdzia jako umiejętności, które nabywa katechizowany $\mathrm{w}$ toku procesu edukacyjno-wychowawczego. W poniższym zestawieniu tabelarycznym możemy wyróżnić istotne treści i kierunki, zmierzające do realizacji tego ważnego zadania katechetycznego.

\begin{tabular}{|c|c|c|}
\hline \multirow{2}{*}{$\begin{array}{l}\text { Cele katechetyczne - } \\
\text { wymagania ogólne }\end{array}$} & \multicolumn{2}{|c|}{ Treści - wymagania szczegółowe } \\
\hline & Wiadomości & Umiejętności ucznia \\
\hline $\begin{array}{l}\text { Przedszkole } \\
\text { Dziecko: } \\
\text { - uczestniczy w procesie wy- } \\
\text { chowania moralno-społecznego, } \\
\text { - nabywa i rozwija umiejętności } \\
\text { społeczne niezbędne do życia } \\
\text { w rodzinie, grupie rówieśniczej i } \\
\text { kontaktach z dorosłymi, }\end{array}$ & $\begin{array}{l}\text { - Przykazanie miłości Boga } \\
\text { i bliźniego. }\end{array}$ & $\begin{array}{l}\text { - przestrzega zasad obowiązują- } \\
\text { cych dziecko Boże i ucznia } \\
\text { Jezusa, } \\
\text { - szanuje starszych, biednych, } \\
\text { chorych i cierpiących, ponieważ } \\
\text { ukochał ich Jezus, } \\
\text { - współdziała z rówieśnikami } \\
\text { podczas zabawy i nauki oraz } \\
\text { pomaga dzieciom i dorosłym na } \\
\text { miarę swoich możliwości. }\end{array}$ \\
\hline $\begin{array}{l}\text { Szkoła Podstawowa, } \\
\text { klasy I-III } \\
\quad \text { Uczeń: } \\
\text { - rozwija umiejętności społeczne } \\
\text { niezbędne do życia w grupie } \\
\text { rówieśników, rodzinie i szkole. }\end{array}$ & $\begin{array}{l}\text { - Wiara źródłem ludzkiej życz- } \\
\text { liwości, pogody ducha, radości. } \\
\text { Pomoc chorym i cierpiącym. } \\
\text { - Dekalog wyrazem troskliwej } \\
\text { miłości Boga wobec ludzi. } \\
\text { - Dobro otrzymywane od Boga. } \\
\text { Sposoby czynienia dobra w } \\
\text { klasie, rodzinie, parafii. } \\
\text { - Postaci biblijne przykładem } \\
\text { życia wiary. Przykłady życia } \\
\text { według Ewangelii. }\end{array}$ & $\begin{array}{l}\text { - podaje przykłady niesienia } \\
\text { pomocy innym, } \\
\text { - wskazuje, jak należy troszczyć } \\
\text { się o dobro wspólne: klasowe, } \\
\text { rodzinne, parafialne, } \\
\text { - odróżnia dobro od zła, } \\
\text { - wykazuje wrażliwość na prze- } \\
\text { jawy dobra i zła, } \\
\text { - przejawia postawę życzliwości } \\
\text { i koleżeństwa wobec rówieśni- } \\
\text { ków. }\end{array}$ \\
\hline
\end{tabular}

\footnotetext{
${ }^{17}$ Por. tamże, s. $17-78$.
} 


\begin{tabular}{|c|c|c|}
\hline $\begin{array}{l}\text { Klasy IV-VI } \\
\text { Uczeń: } \\
\text { - rozpoznaje swoje obowiązki } \\
\text { wobec najbliższego otoczenia, } \\
\text { rodziny i szkoły, } \\
\text { - wyraża opinie i wartościuje } \\
\text { zjawiska społeczno-religijne na } \\
\text { poziomie społeczności szkolnej } \\
\text { i społeczności lokalnej. }\end{array}$ & $\begin{array}{l}\text { - Dekalog i Błogosławieństwa } \\
\text { wyrazem troski Boga o szczę- } \\
\text { ście człowieka. } \\
\text { - Wartość życia i zdrowia oraz } \\
\text { ich zagrożenia. } \\
\text { - Trudne sytuacje życiowe: } \\
\text { choroba, śmierć. }\end{array}$ & $\begin{array}{l}\text { - wskazuje różnicę między do- } \\
\text { brem i złem w podstawowych } \\
\text { sytuacjach moralnych, } \\
\text { - dostrzega konsekwencje dobra } \\
\text { i zła, } \\
\text { - rozumie, co znaczy być odpo- } \\
\text { wiedzialnym, } \\
\text { - wskazuje chrześcijańskie moty- } \\
\text { wy wyborów w codziennym } \\
\text { życiu, } \\
\text { - przejawia refleksyjną postawę } \\
\text { wobec różnych sytuacji życio- } \\
\text { wych i zobowiązań moralnych. }\end{array}$ \\
\hline $\begin{array}{l}\text { Gimnazjum } \\
\quad \text { Uczeń: } \\
\text { - w oparciu o posiadaną wiedzę } \\
\text { wypracowuje względnie stałe } \\
\text { zachowania, reakcje poznawcze, } \\
\text { emocjonalnie umotywowane } \\
\text { wartościami najwyższymi, } \\
\text { odnosząc je zwłaszcza do miło- } \\
\text { ści Boga, Kościoła, Ojczyzny i } \\
\text { rodziny, } \\
\text { - w sposób twórczy wykorzystu- } \\
\text { je opinie, oceny, które o sobie } \\
\text { słyszy, do budowania właści- } \\
\text { wych relacji międzyludzkich. }\end{array}$ & $\begin{array}{l}\text { - Pojęcie miłości i sposoby jej } \\
\text { przeżywania. } \\
\text { - Świętość w rozmaitych for- } \\
\text { mach życia. } \\
\text { - Osiem Błogosławieństw jako } \\
\text { podstawa życia w łasce Bożej. }\end{array}$ & $\begin{array}{l}\text { - charakteryzuje obowiązki wyni- } \\
\text { kające z poszczególnych przyka- } \\
\text { zań Bożych, } \\
\text { - interpretuje rozumienie pojęcia } \\
\text { prawdziwej miłości w różnych } \\
\text { aspektach życia ludzkiego, } \\
\text { - wykazuje związek między } \\
\text { życiem Błogosławieństwami } \\
\text { i życiem w łasce Bożej, } \\
\text { - ilustruje właściwe zachowania } \\
\text { dzieci względem rodziców, } \\
\text { - uzasadnia świętość życia ludz- } \\
\text { kiego. }\end{array}$ \\
\hline 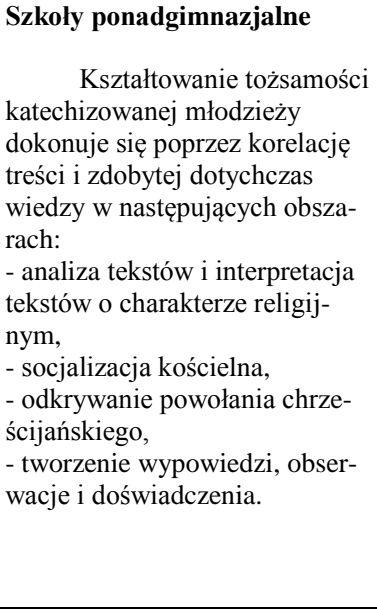 & $\begin{array}{l}\text { - Osoba i jej godność, wolność } \\
\text { osoby. } \\
\text { - Powołanie chrześcijańskie. } \\
\text { - Rodzaje powołań w Kościele } \\
\text { i sposoby ich realizacji. Realiza- } \\
\text { cja powołania w Kościele } \\
\text { lokalnym. }\end{array}$ & $\begin{array}{l}\text { - odczytuje człowieczeństwo } \\
\text { jako dar zadany człowiekowi, } \\
\text { - charakteryzuje wybrane drogi } \\
\text { powołania chrześcijańskiego, } \\
\text { - hierarchizuje nabywane przez } \\
\text { chrześcijanina cnoty, ze szcze- } \\
\text { gólnym uwzględnieniem miło- } \\
\text { ści, } \\
\text { - ocenia rozumienie godności } \\
\text { człowieka w różnych systemach } \\
\text { etycznych, } \\
\text { - ocenia konkretne przypadki } \\
\text { zachowań moralnych, } \\
\text { - analizuje rolę samowychowa- } \\
\text { nia, pracy nad charakterem } \\
\text { i odkrywania talentów w reali- } \\
\text { zacji powołania, } \\
\text { - opisuje pracę jako drogę } \\
\text { realizacji powołania }{ }^{18} \text {. }\end{array}$ \\
\hline
\end{tabular}

\section{Uczynki miłosierdzia w wybranych programach i materialach katechetycznych}

W celu ożywienia i skutecznego prowadzenia procesu katechetycznego we współczesnych działaniach edukacyjnych niezastąpioną rolę odgrywają, obok podstawy programowej katechezy także programy nauczania, podręczniki i inne

\footnotetext{
${ }^{18}$ Por. tamże, s. $17-78$.
} 
pomoce dydaktyczne. W posłudze katechetycznej Kościoła ważnym narzędziem dydaktycznym jest również Katechizm Kościoła katolickiego. Analizując zawarte w Katechizmie nauczanie Kościoła na temat uczynków miłosierdzia, należy stwierdzić, iż obejmuje ono wszystkie cztery podstawowe wymiary formacyjne, a mianowicie rozwijanie wiary, życie sakramentalne, formację moralną i wychowanie do modlitwy. Najpierw, w części pierwszej zatytułowanej Wyznanie wiary, w numerze 544 autorzy Katechizmu zwracają uwagę na potrzebę aktywnej miłości ubogich, jako warunku wejścia do królestwa niebieskiego, a także omawiając zagadnienia eschatologiczne, wskazują na ostrzeżenie przed potępieniem, jakie kieruje Jezus Chrystus do wiernych, jeśli ci nie wyjdą naprzeciw ważnym potrzebom ubogich i maluczkich ${ }^{19}$. Kolejnym wymiarem kształtowania wrażliwości i właściwej postawy moralnej wierzących jest praktyka życia sakramentalnego, praktykowanie uczynków miłosierdzia, dzięki świadomości obecności Chrystusa nie tylko w znakach sakramentalnych, ale także - jak sam o tym nauczał - w ubogich, chorych i więźniach ${ }^{20}$. Fundamentalnym zaś miejscem nauczania Katechizmu na temat chrześcijańskiej praktyki miłosierdzia jest część trzecia, poświęcona formacji moralnej - Życie w Chrystusie. Czytamy w niej, iż uczynkami miłosierdzia sa dzieła milości, przez które przychodzimy z pomoca naszemu bliźniemu w potrzebach jego ciata i duszy. Pouczać, radzić, pocieszać, umacniać, jak również przebaczać i krzywdy cierpliwie znosić - to uczynki miłosierdzia co do duszy.

Uczynki mitosierdzia co do ciała polegaja zwłaszcza na tym, by głodnych nakarmić, bezdomnym dać dach nad głowa, nagich przyodziać, chorych i więźniów nawiedzać, umarlych pogrzebać. Spośród tych czynów jałmużna dana ubogim jest jednym ze szczególnych świadectw miłości braterskiej; jest ona także praktykowaniem sprawiedliwości, która podoba się Bogu ${ }^{21}$. Miłość ubogich - w świetle nauki Katechizmu - jest znakiem, dzięki któremu Chrystus rozpoznaje swoich wiernych i im błogosławi, a jednym ze szczególnych momentów do praktykowania uczynków miłości jest dla chrześcijanina dzień Pański - niedziela oraz troska o pogrzebanie ciała ludzkiego ${ }^{22}$. Swoiste dopełnienie nauki Katechizmu i zachęta do praktykowania uczynków miłości zawarta jest w części czwartej, poświęconej Modlitwie chrześcijańskiej. Omówienie poszczególnych wezwań modlitwy Ojcze nasz, szczególnie zaś w wezwaniu Chleba naszego powszedniego daj nam dzisiaj, znajdujemy bezpośredni apel do

${ }^{19}$ Por. Katechizm Kościoła katolickiego. Pallottinum - Poznań 1994 nr 544, 1033 [dalej KKK].

${ }^{20}$ Por. KKK 1373.

${ }^{21}$ Tamże, 2447.

${ }^{22}$ Por. tamże, 2443; 2185; 2300. 
czynnej odpowiedzialności wobec głodujących braci, która uwidacznia się w postawie osobistej i solidarności z całą rodziną ludzką ${ }^{23}$.

Podobny schemat nauczania treści związanych z uczynkami miłosierdzia, został zastosowany w Programie nauczania religii rzymskokatolickiej w przedszkolach $i$ szkołach oraz w tworzonych na podstawie powyższego dokumentu i aktualnie obowiązujących, programach i podręcznikach do nauczania religii w Polsce. Analizując wybrane ogólnopolskie materiały i pomoce katechetyczne, można stwierdzić, iż bezpośrednio temat uczynków miłosierdzia pojawia się kilkakrotnie, na poszczególnych etapach edukacyjnych, przy omawianiu zagadnień dotyczących Dekalogu i przykazania miłości Boga i bliźniego, a pośrednio także przy treściach katechetycznych na temat funkcjonowania wspólnoty Kościoła, życia sakramentalnego i nauki wynikającej z rozważania słowa Bożego. Planowanie dydaktyczne zakłada zatem naukę o uczynkach miłosierdzia względem ciała i ducha, przywołując obrazy biblijne, szczególnie naukę Jezusa Chrystusa o Sądzie ostatecznym z Ewangelii według św. Mateusza 25, 34-36.40, a także wskazanie normy moralnej w następującym układzie treści:

\begin{tabular}{|c|c|c|c|}
\hline $\begin{array}{l}\text { Etap } \\
\text { edukacyjny }\end{array}$ & Klasa & Blok tematyczny z Programu ${ }^{24}$ & $\begin{array}{l}\text { Proponowane tematy } \\
\text { w wybranych Podręcznikach } \\
\text { i Kartach Pracy }\end{array}$ \\
\hline Przedszkole & $\begin{array}{l}\text { cztero- i pięcio- } \\
\text { latki }\end{array}$ & $\begin{array}{l}\text { Dobry Bóg kocha mnie } \\
\text { i moja rodzinę } \\
\text { Kocham Pana Boga, bo jestem } \\
\text { Jego dzieckiem } \\
\text { Jesteśmy uczniami Pana Jezusa i } \\
\text { chcemy Go naśladować }\end{array}$ & $\begin{array}{l}\text { - Pan Bóg troszczy się o nas } \\
\text { - Od św. Rodziny uczymy się } \\
\text { miłości } \\
\text { - Bóg Ojciec uczy nas czynić } \\
\text { dobro } \\
\text { - Moi bliscy } \\
\text { - Syn Boży ogłosił światu } \\
\text { Dobrą Nowinę } \\
\text { - Uczniowie Pana Jezusa }{ }^{26} \text {. }\end{array}$ \\
\hline
\end{tabular}

${ }^{23}$ Por. tamże, 2831

${ }^{24}$ Komisja Wychowania Katolickiego Konferencji Episkopatu Polski: Program nauczania religii..., dz. cyt.

${ }^{25}$ Ze względu na bogatą ofertę wydawniczą, obowiązujących w Polsce i poszczególnych diecezjach podręczników do nauki religii, niniejsze zestawienie tabelaryczne przedstawia tematy, proponowane tylko w wybranych ogólnopolskich podręcznikach i kartach pracy, dopuszczonych do użytku ogólnopolskiego.

${ }^{26}$ Por. Pan Bóg kocha dzieci. Podręcznik dla dzieci trzyletnich i czteroletnich. Red. J. S z pe t, D. J a c k ow i a k. Poznań 2012; Jesteśmy dziećmi Bożymi. Podręcznik dla dzieci pięcioletnich. Red. J. S z p e t, D. J a c k o w i a k. Poznań 2011 s. 46-47. 64-67. 


\begin{tabular}{|c|c|c|c|}
\hline \multirow[t]{4}{*}{$\begin{array}{l}\text { Szkoła Podsta- } \\
\text { wowa }\end{array}$} & I & $\begin{array}{l}\text { Czuwam z Maryja i innymi świę- } \\
\text { tymi -Zróbcie, co wam powie }\end{array}$ & $\begin{array}{l}\text { - Kochamy bliskich } \\
\text { - Miłujmy się wzajemnie } \\
\text { - Uczymy się kochać jak Pan } \\
\text { Jezus }{ }^{27} \text {. }\end{array}$ \\
\hline & II & Dzielimy się-jak Ty, Panie & $\begin{array}{l}\text { - Jesteśmy wezwani do } \\
\text { dzielenia się z innymi } \\
\text { - Jezus uczy nas miłości } \\
\text { bliźniego. Zadanie w Kartach } \\
\text { pracy: Co jeszcze dziś mo- } \\
\text { żesz uczynić? } \\
\text { - Jezus wzywa nas do pomo- } \\
\text { cy }^{28} \text {. }\end{array}$ \\
\hline & III & Wypetniamy Przykazania & $\begin{array}{l}\text { - Pan Bóg prowadzi nas przez } \\
\text { życie } \\
\text { - Niedziela - dzień poświę- } \\
\text { cony Panu Bogu } \\
\text { - Największe przykazanie } \\
\text { - Mamy świadczyć o Bogu } \\
\text { - Prawdziwy przyjaciel jest } \\
\text { apostołem } \\
\text { - Dziesięć słów o miłości do } \\
\text { Boga i ludzi } \\
\text { - Szczęśliwi ubodzy w duchu } \\
\text { - Kochać jak Jezus }{ }^{29} \text {. }\end{array}$ \\
\hline & IV & $\begin{array}{l}\text { Przykazanie milości fundamentem } \\
\text { przyjaźni } \\
\text { Uczę się kochać Pana Boga i } \\
\text { ludzi }\end{array}$ & $\begin{array}{l}\text { - „Będziesz miłował” Mt } \\
22,37 \\
\text { - Dekalog } \\
\text { - Kochać drugiego człowieka } \\
\text { jak siebie samego } \\
\text { - Uczynki miłosierdzia } \\
\text { - Pamiętam o innych } \\
\text { - Dzielę się z innymi } \\
\text { - Doświadczam opieki Pana } \\
\text { Boga }^{30} \text {. }\end{array}$ \\
\hline
\end{tabular}

${ }^{27}$ Por. Jesteśmy $w$ rodzinie Pana Jezusa. Red. J. S z pe t, D. J a ck ow i a k. Poznań 2011 s. 72-73. 80-81. 106-107; Jesteśmy w rodzinie Pana Jezusa. Red. W. K u b i k. Kraków 2011 s.50. 82. $114-115$.

${ }^{28}$ Por. Kochamy Pana Jezusa. Red. J. S z p e t, D. J a c k o w i a k. Poznań 2012 s. 28-31. 70. 98. 114; Kochamy Pana Jezusa. Red. W. K u b i k. Kraków 2012 s.14. 30. 52. 126-128.

${ }^{29}$ Por. Przyjmujemy Pana Jezusa. Red. J. S z p e t, D. J a c k ow i a k. Poznań 2013 s. 38. 48-49. 126; Przyjmujemy Pana Jezusa. Red. W. K u b i k. Kraków 2013 s. 48. 18-129. 137.

${ }^{30}$ Por. Jestem chrześcijaninem. Red. J. S z p e t, D. J a c k o w i a k. Poznań 2011 s. 84-93. 104-104; Zaproszeni przez Boga. Red. Z. M a r e k. Kraków 2012 s. 60. 74-75. 108-109. 


\begin{tabular}{|c|c|c|c|}
\hline & $\mathrm{V}$ & $\begin{array}{l}\text { Bóg posyła Jezusa } \\
\text { Bóg poucza przez Jezusa }\end{array}$ & $\begin{array}{l}\text { - Żyć według Dekalogu } \\
\text { - Być wiernym Bogu } \\
\text { - Ewangeliczne błogosła- } \\
\text { wieństwa } \\
\text { - Czynię miłosierdzie } \\
\text { - Szczere dobro }{ }^{31} \text {. }\end{array}$ \\
\hline & VI & $\begin{array}{l}\text { Życie pierwszych wspólnot chrze- } \\
\text { ścijańskich }\end{array}$ & $\begin{array}{l}\text { - Nieść pomoc } \\
\text { - Święta Jadwiga Śląska - } \\
\text { wzór troski o potrzebujących } \\
\text { - Wierni miłości - Caritas } \\
\text { - Udzielamy jałmużny }{ }^{32} \text {. }\end{array}$ \\
\hline \multirow[t]{3}{*}{ Gimnazjum } & $\mathrm{I}$ & Stowo natchnione & $\begin{array}{l}\text { - Prawo Królestwa Bożego } \\
\text { - Wiara bez uczynków jest } \\
\text { martwa } \\
\text { - Zagubionych odszukam } \\
\text { - Ludzie Jezusa } \\
\text { - Ujrzymy siebie, jakimi } \\
\text { jesteśmy }{ }^{33} \text {. }\end{array}$ \\
\hline & II & $\begin{array}{l}\text { Wędrówka ku dobru } \\
\text { Drogowskazy na drodze ku } \\
\text { szczęściu }\end{array}$ & $\begin{array}{l}\text { - Namaszczenie chorych - } \\
\text { troska o cierpiących } \\
\text { - cały dział: Szukam dobra } \\
\text { i Wskazuję ci drogę }^{34} \text {. }\end{array}$ \\
\hline & III & $\begin{array}{l}\dot{Z} y j e ̨, \text { aby kochać } \\
\text { Ojcze nasz }\end{array}$ & $\begin{array}{l}\text { - Opieka paliatywna } \\
\text { - Pokochaj drugiego } \\
\text { - cały dział: Mocni w działa- } \\
\text { niu } \\
\text { - Apostoł Miłości }{ }^{35} \text {. }\end{array}$ \\
\hline $\begin{array}{l}\text { Szkoły ponad- } \\
\text { gimnazjalne }\end{array}$ & $\mathrm{I}$ & Co mam czynić? & $\begin{array}{l}\text { - Świadectwo chrześcijan } \\
\text { - Miłosierdzie zamienić } \\
\text { w czyn } \\
\text { - Takie jest prawo miłości } \\
\text { - Ideał ucznia Chrystusa }{ }^{36} \text {. }\end{array}$ \\
\hline
\end{tabular}

${ }^{31}$ Por. Wierzę w Boga. Red. J. S z p e t, D. J a c k o w i a k. Poznań 2012 s. 56-63. 118-127; Obdarowani przez Boga. Red. Z. M a r e k. Kraków 2013 s. 83. 98. 102.

${ }^{32}$ Por. Wierze w Kościót. Red. J. S z p e t, D. J a c k o w i a k. Poznań 2013 s. 88-89, 142 146; Przemienieni przez Boga. Red. Z. M a r e k. Kraków 2014 s. 46. 54-55. 88-89.

${ }^{33}$ Por. Spotkanie ze Stowem. Red. J. S z p e t, D. J a c k ow i a k. Poznań 2011 s. 74-79; Szukam was. Red. W. K u b i k. Kraków 2011 s. 62. 78. 86.

${ }^{34}$ Por. Aby nie ustać w drodze. Red. J. S z p e t, D. J a c k o wi a k. Poznań 2012 s. 36; Jestem z wami. Red. W. K u b i k. Kraków 2012 s. 69-120.

35 Por. Żyć w miłości Boga. Red. J. S z p e t, D. J a c k ow i a k. Poznań 2013 s. 42-43; Chodźmy razem. Red. W. Ku b i k. Kraków 2013 s. 103-114.

${ }^{36}$ Por. Moje miejsce w Kościele. Red. J. S z p e t, D. J a c k o w i a k. Poznań 2011 s. 95. 177. 185; Jestem świadkiem Chrystusa w Kościele. Red. Z. M a r e k. Kraków 2011 s. 146. 


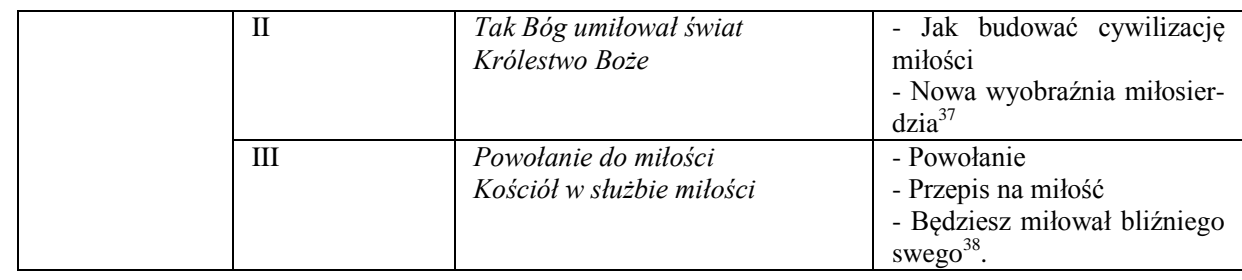

Obok planowania programowego nauki religii w szkole, konieczne jest również uwzględnienie programów katechezy parafialnej, której zadaniem jest współdziałanie i niejako dopełnienie katechezy szkolnej. Warto w tym miejscu podkreślić fakt, prowadzonej we wspólnotach parafialnych katechezy sakramentalnej przygotowującej dzieci, młodzież oraz rodziców do I Komunii świętej, bierzmowania i życia małżeńskiego. W materiałach formacyjnych, obecnych na rynku wydawniczym istnieje szereg cennych treści, pogłębiających sens i wartość życia chrześcijańskiego, opartego na miłości Boga i bliźniego.

Cenną pomoc w parafialnej pracy katechetycznej stanowi, między innymi wydany w 2011 roku Youcat Polski, Katechizm Kościoła katolickiego dla młodych, w którym również znajdujemy obszerny materiał obejmujący zagadnienie chrześcijańskich dzieł miłosierdzia, wymieniający uczynki miłosierdzia względem ciała i względem ducha ${ }^{39}$. Podobne treści zachęty do służby człowiekowi przez miłość, na wzór bł. Matki Teresy z Kalkuty, prezentuje autor Youcat Polski Bierzmowanie, w materiale katechetycznym skierowanym do młodzieży uczestniczącej w przygotowaniu do przyjęcia sakramentu dojrzałości chrześcijańskiej $^{40}$. Ciekawą inicjatywą jest również przygotowany przewodnika dla młodzieży - Wierzę, bo chcę! W proponowanym materiale znajdujemy tematy, których celem jest pogłębienie w katechizowanych treści odnoszących się do chrześcijańskiej postawy miłosierdzia wobec bliźnich, wynikającej z Dekalogu i przesłania Ewangelii. Jedynym mankamentem, powyższego przewodnika jest brak przykazania miłości Boga i bliźniego w części nazwanej „skrócony

\footnotetext{
${ }^{37}$ Por. Moje miejsce w świecie. Red. J. S z p e t, D. J a c k o w i a k. Poznań 2012 s. 106-112; Drogi świadków Chrystusa w świecie. Red. Z. M a r e k Kraków 2013 s. 153-155; Świadek Chrystusa w świecie. Red. S. Ł a b e n d o w i c z. Radom 2013.

${ }^{38}$ Por. Moje miejsce w rodzinie. Red. J. S z p e t, D. J a c k o w i a k. Poznań 2014 s. 112; Ze Zmartwychwstałym $w$ rodzinie. Red. Z. M a re k. Kraków 2001 s. 48; Mocni miłościa. Red. T. P a nuś, R. Chrzanowska. Kraków 2015 s. 185; Z wiarq na progu mitości. Red. J. Czerkawski, E. Kondrak, B. Nosek. Kielce 2000; Drogi świadków Chrystusa w rodzinie. Red. Z. M a r e k. Kraków 2014 s. 167. 186.

${ }^{39}$ Por. Youcat Polski. Katechizm Kościoła katolickiego dla młodych. Częstochowa 2011 s. 246-247.

${ }^{40}$ Por. B. M e u s e r, N. B a e r: Youcat Polski. Bierzmowanie. Częstochowa 2014 s. 85,
} 69-70. 
katechizm", w miejscu omawiania Dekalogu i zadań chrześcijańskich, wynikających z tej normy moralnej ${ }^{41}$.

Kolejnym obszarem działań katechetycznych, podejmującym zagadnienie chrześcijańskich uczynków miłości, jest katecheza parafialna młodzieży ponadgimnazjalnej, oparta na programie przygotowanym przez Komisję Wychowania Katolickiego i Radę do Spraw Rodziny Konferencji Episkopatu Polski. W dokumencie tym znajdujemy konkretne cele, treści i zadania katechetyczne, które mają zmierzać do kształtowania w katechizowanych postawy dojrzałości chrześcijańskiej, odpowiedzialności i miłości wobec bliźnich, realizowanej na drodze własnego powołania. Przygotowany program, zakłada między innymi uczestnictwo w cyklu spotkań katechetycznych w parafii, prowadzonych przez kompetentny zespół katechetyczny, w oparciu o podręczniki i materiały formacyj$\mathrm{ne}^{42}$. Wprowadzenie zagadnień dotyczących świadectwa życia chrześcijańskiego, wyrażonego w miłości do Boga i człowieka, stanowi ważny element w katechizacji młodzieży, która kształtując własną wrażliwość i świat wartości, staje przed podjęciem ważnych decyzji, związanych $\mathrm{z}$ wyborem drogi powołania i życia.

Stosunkowo nową i dynamicznie rozwijającą się na terenie szkół i wspólnot parafialnych inicjatywą, są Parafialne i Szkolne Koła Caritas. Prowadzone pod patronatem Caritas w szkołach i parafiach Koła Caritas, w świetle założeń statutowych mają na celu prowadzenie formacji charytatywnej i koordynować czynne dzieła miłosierdzia. Formacja charytatywna skupia się między innymi na uwrażliwianiu członków Kół Caritas na różne obszary ludzkiej biedy i krzewieniu ducha czynnej miłości bliźniego, a także na większym zrozumieniu i pogłębieniu nauki Jezusa Chrystusa o miłosierdziu. Na płaszczyźnie działania, dzięki wsparciu liderów członkowie Kół Caritas mogą rozpoznawać konkretne potrzeby ludzi w najbliższym środowisku i współdziałać w dziele pomocy ${ }^{43}$. Owocne działanie i rozwój Szkolnych i Parafialnych Kół Caritas, stał się okazją do wprowadzania nowych form katechezy o chrześcijańskich uczynkach miłości, które charakteryzują się nie tylko przekazywaniem wiedzy teoretycznej, ale mają za zadanie kształtowanie w katechizowanych odpowiednich postaw i motywowanie do wprowadzania w praktykę codziennego życia zasad poznanych na katechezie. Właściwe wypełnianie dzieł miłosierdzia potrzebuje nie tylko

${ }^{41}$ Por. P. K r z y ż e w s k i: Wierze, bo chcę! Przygotowanie do bierzmowania. Poznań 2014 s. $39.49-70$.

${ }^{42}$ Por. Komisja Wychowania Katolickiego, Rada do Spraw Rodziny Konferencji Episkopatu Polski: Program katechezy parafialnej młodzieży szkót ponadgimnazjalnych. Kraków 2004 s. 1115; W oparciu o cytowany Program katechezy parafialnej powstały opracowania w postaci podręczników np. Przypatrzcie się powolaniu waszemu. J. S z p e t, D. B r y l. Poznań 2004; Drogi ścieżki powołania. Red. Z. M a r e k. Kraków 2004.

${ }^{43}$ Por. Podręcznik opiekuna szkolnego koła caritas. Red. M. G a w e ł. Białystok, Warszawa 2009 s. 19. 
dobrego planowania i koordynacji w przestrzeni społecznej, ale przede wszystkim solidnej formacji duchowej i intelektualnej. Przygotowany i wprowadzony do użytku Podręcznik opiekuna szkolnego koła caritas, stał się niewątpliwie cennym źródłem wiedzy i pomocą w prowadzeniu pogłębionej formacji. Oprócz podstawowych informacji, czym jest szkolne koło caritas, kim jest wolontariusz i jaki jest system wolontariatu w prawie Polskim, znajdziemy w omawianym Podręczniku usystematyzowany Program zajęć wychowawczych i formacji charytatywnej na poszczególne etapy edukacyjne, a także konspekty do przeprowadzenia tychże zajęć ${ }^{44}$. Na szczególną uwagę, ze względu na omawiane $\mathrm{w}$ tym opracowanie zagadnienie uczynków miłosierdzia względem ciała i względem ducha, zasługują konspekty prezentujące wzory osób, które pełniły dzieła miłosierdzia, między innymi bł. Matki Teresy z Kalkuty, św. Brata Alberta Chmielowskiego, św. Jana Pawła II, bł. Piotra Jerzego Frassati, Ireny Sen$\mathrm{dler}^{45}$. W proponowanych materiałach formacyjnych dla członków szkolnych kół caritas, w sposób pogłębiony i rzetelny omawia się także poszczególne uczynki miłosierdzia, odnosząc do wzorców i obrazów ewangelicznych opieki nad chorymi, cierpiącymi i starszymi; przyjmowania uchodźców; pomocy biednym $^{46}$. Biorąc pod uwagę zgromadzony w Podręczniku opiekuna szkolnego koła caritas materiał, zaproponowane metody i formy pracy dydaktycznej, stanowią cenną pomoc $\mathrm{w}$ realizacji posługi katechetycznej w zakresie uwrażliwiania i kształtowania chrześcijańskiej postawy miłości.

Papież Franciszek zachęcając wiernych Kościoła do odkrycia na nowo uczynków miłosierdzia, na sposób katechetyczny wymienia poszczególne uczynki względem ciała: głodnych nakarmić, spragnionych napoić, nagich przyodziać, przybyszów $w$ dom przyjać, więźniów pocieszać, chorych nawiedzać, umartych pogrzebać. I nie zapominamy o uczynkach miłosierdzia wzgledem ducha: watpiacym dobrze radzić, nieumiejętnych pouczać, grzeszacych upominać, strapionych pocieszać, krzywdy cierpliwie znosić, urazy chętnie darować, modlić się za żywych i umartych ${ }^{47}$. Warto podkreślić w tym miejscu wartość metody, którą posługuje się Ojciec święty, bowiem we współczesnym systemie edukacji i materiałach katechetycznych, zauważa się potrzebę nieustanego przypominania i utrwalania nauczanych treści, w formie krótkich syntez wiary i norm moralnych. Ta prosta metoda katechizmowa została zastosowana między innymi w opracowanych katechizmach dla dorosłych, gdzie obok systematycznego wykładu nauki Kościoła na poszczególne tematy, umieszcza się dodatek w formie „małego katechizmu”. Przykładem może być dodatek Prawdy

\footnotetext{
${ }^{44}$ Por. Tamże.

${ }^{45}$ Por. Tamże, s. 91-93. 145-149. 182-186.

${ }^{46}$ Por. Tamże, s. 108-109. 121-122. 135-136. 169-170,

${ }^{47}$ Franciszek: Bulla Misericordiae vultus, dz. cyt. nr 15.
} 
nauki katolickiej w Kompendium katechizmu Kościoła katolickiego ${ }^{48}$, a także w Katechizmie dla dorosłych, Wydawnictwa WAM Taka jest wiara Kościota ${ }^{49}$, czy w opracowaniu Wierzę. Mały Katechizm katolicki ${ }^{50}$. Biorąc pod uwagę dynamizm i różnych adresatów posługi katechetycznego, warto podkreślić fakt, iż w procesie planowania przepowiadania katechetycznego uwzględnia się również katechezę dorosłych. Dzięki temu cały proces działalności katechetycznej Kościoła staje w służbie integralnego rozwoju człowieka i troski o życie i zbawienie, które obiecuje Jezus Chrystus tym, którzy Go szczególnie naśladują w uczynkach miłosierdzia. Papież Franciszek zwraca naszą uwagę, kreśląc perspektywę eschatologiczną w słowach: W każdym z tych ,najmniejszych” jest obecny sam Chrystus. Jego ciało staje się znów widoczne jako umęczone, poranione, ubiczowane, niedożywione, w ucieczce..., abyśmy mogli je rozpoznać, dotknać i pomóc z troska. Nie zapominajmy o stowach św. Jana od Krzyża: "Pod wieczór życia będa cię sądzić z miłości»"

Podsumowując powyższe opracowanie i podjętą analizę aktualnie obowiązujących dokumentów planowania dydaktycznego katechezy w Polsce oraz podręczników do nauki religii w zakresie przekazywanej wiedzy o uczynkach miłosierdzia i chrześcijańskiej postawie miłości, należy stwierdzić, iż zaproponowane treści, metody i formy na poszczególnych etapach katechizacji, wpisują się znacząco w proces formacji moralnej. Działania zmierzające do ukazania właściwego świata wartości i kształtowania dojrzałej osobowości, na podstawie poznanego prawa i normy moralnej stają się skuteczne w budowaniu odpowiedzialnych postaw i relacji interpersonalnych. Mając jednak świadomość, iż wychowanie moralne to proces długotrwały, uwzględniający wiele czynników zewnętrznych i wewnętrznych, które mogą mieć wpływ pozytywny lub negatywny, warto z nowym zapałem podjąć w przepowiadaniu katechetycznym apel i życzenie Papieża Franciszka, do pochylenia się nad uczynkami miłosierdzia we własnym życiu i otaczającym środowisku społecznym. Odpowiadając na głos Kościoła i wierząc w działanie Ducha Świętego w posłudze katechetycznej, należy - jak uczy Papież Franciszek - poprzez aktywną, pogkębioną i odpowiedzialną katechezę, podejmować działania zmierzające do kształtowania postawy solidarności i pocieszenia, wyrywającą z obojętności, przyzwyczajenia, hipokryzji, egoizmu i cynizmu, aby katechizowani mogli z jeszcze większą odwagą i pokojem serca otworzyć oczy, dostrzec biedę świata i poczuć się sprowokowani, do niesienia miłosiernej pomocy, wyrażającej się przez ciepło naszej obecności, przyjaźni i braterstwa ${ }^{52}$. Autentyczność i skuteczność wspó1-

${ }^{48}$ Por. Kompendium Katechizmu Kościoła katolickiego. Kielce 2005 s. 216-217.

${ }^{49}$ Por. Taka jest wiara Kościoła. Katechizm dla dorosłych. Red. Z. M a r e k. Kraków 2009 s. $217-218$.

\footnotetext{
${ }^{50}$ Por. E. B e c k: Wierzę. Mały Katechizm katolicki. Tarnów, Poznań 2001 s. 148-152.

${ }^{51}$ Franciszek: Bulla Misericordiae vultus, dz. cyt. nr 15.

${ }^{52}$ Por. Tamże.
} 
czesnej posługi katechetycznej, wyraża się bowiem przede wszystkim przez owocne i szlachetne życie katechizowanych, ich naśladowanie i zażyłość z Jezusem Chrystusem.

\section{Bibliografia}

Aby nie ustać w drodze. Red. J. Szpet, D. Jackowiak. Poznań 2012.

Beck E.: Wierzę. Maty Katechizm katolicki. Tarnów - Poznań 2001.

Chodźmy razem. Red. W. Kubik. Kraków 2013.

Drogi ścieżki powotania. Red. Z. Marek. Kraków 2004.

Drogi świadków Chrystusa w rodzinie. Red. Z. Marek. Kraków 2014.

Drogi świadków Chrystusa w świecie. Red. Z. Marek. Kraków 2013.

Franciszek: Bulla Misericordiae vultus. Rzym 2015.

Jestem chrześcijaninem. Red. J. Szpet, D. Jackowiak. Poznań 2011.

Jestem świadkiem Chrystusa w Kościele. Red. Z. Marek. Kraków 2011.

Jestem z wami. Red. W. Kubik. Kraków 2012.

Jesteśmy dziećmi Bożymi. Red. J. Szpet, D. Jackowiak. Poznań 2011.

Jesteśmy w rodzinie Pana Jezusa. Red. J. Szpet, D. Jackowiak. Poznań 2011.

Jesteśmy w Rodzinie Pana Jezusa. Red. W. Kubik. Kraków 2011.

Katechizm Kościoła katolickiego 1994.

Kochamy Pana Jezusa. Red. W. Kubik. Kraków 2012.

Kochamy Pana Jezusa. Red. J. Szpet, D. Jackowiak. Poznań 2012.

Komisja Wychowania Katolickiego. Rada do Spraw Rodziny Konferencji Episkopatu Polski: Program katechezy parafialnej młodzieży szkót ponadgimnazjalnych. Kraków 2004.

Komisja Wychowania Katolickiego Konferencji Episkopatu Polski: Program nauczania religii rzymskokatolickiej w przedszkolach i szkołach. Kraków 2010.

Komisja Wychowania Katolickiego Konferencji Episkopatu Polski: Uchwała z dnia 9 czerwca 2010 r. w sprawie obowiazywania „Podstawy programowej katechezy Kościoła katolickiego w Polsce”, ,Katecheta” 9: 2010.

Kompendium Katechizmu Kościoła katolickiego. Kielce 2005.

Konferencja Episkopatu Polski: Podstawa programowa katechezy Kościoła katolickiego w Polsce. Kraków 2010.

Kongregacja ds. Duchowieństwa: Dyrektorium Ogólne o Katechizacji 1998.

Krzyżewski P.: Wierzę, bo chcę! Przygotowanie do bierzmowania. Poznań 2014.

Kupisiewicz Cz., Kupisiewicz M.: Stownik pedagogiczny. Warszawa 2009.

Meuser B., Baer N.: Youcat Polski. Bierzmowanie. Częstochowa 2014.

Ministerstwo Edukacji Narodowej: O reformie programowej. I etap edukacyjny ksztatcenie zintegrowane. Biblioteczka Reformy. Warszawa 1999.

Mocni miłościa. Red. T. Panuś, R. Chrzanowska. Kraków 2015.

Moje miejsce w Kościele. Red. J. Szpet, D. Jackowiak. Poznań 2011.

Moje miejsce w rodzinie. Red. J. Szpet, D. Jackowiak. Poznań 2014.

Moje miejsce w świecie. Red. J. Szpet, D. Jackowiak. Poznań 2012.

Obdarowani przez Boga. Red. Z. Marek. Kraków 2013. 
Pan Bóg kocha dzieci. Red. J. Szpet, D. Jackowiak. Poznań 2012.

Podręcznik opiekuna Szkolnego Koła Caritas. Red. J. Czerkawski, E. Kondrak, B. Nosek. Białystok - Warszawa 2009.

Przemienieni przez Boga. Red. Z. Marek. Kraków 2014.

Przyjmujemy Pana Jezusa. Red. W. Kubik. Kraków 2013.

Przyjmujemy Pana Jezusa. Red. J. Szpet, D. Jackowiak. Poznań 2013.

Przypatrzcie się powołaniu waszemu. Red. J. Szpet, D. Bryl. Poznań 2004.

Spotkanie ze Stowem. Red. J. Szpet, D. Jackowiak. Poznań 2011.

Szpet J.: Dydaktyka katechezy. Poznań 1999.

Szukam was. Red. W. Kubik. Kraków 2011.

Świadek Chrystusa w świecie. Red. S. Łabendowicz. Radom 2013.

Taka jest wiara Kościoła, Katechizm dla dorostych. Red. Z. Marek. Kraków 2009.

Wierze w Boga. Red. J. Szpet, D. Jackowiak. Poznań 2012.

Wierze w Kościót. Red. J. Szpet, D. Jackowiak. Poznań 2013.

Youcat Polski. Katechizm Kościoła katolickiego dla młodych. Częstochowa 2011.

$Z$ wiara na progu milości. Red. Czerkawski J., Kondrak E., Nosek. Kielce 2000.

Zaproszeni przez Boga. Red. Z. Marek. Kraków 2012.

Ze Zmartwychwstatym w rodzinie. Red. Z. Marek. Kraków 2001.

Żyć w milości Boga. Red. J. Szpet, D. Jackowiak. Poznań 2013.

\section{ABSTRACT}

\section{The corporal and spiritual works of mercy in catechesis}

Pope Francis in the Bull Misericordiae vultus, declaring Extraordinary Jubilee Charity, among the many demands and recommendations, invites the faithful of the Church of hot desire for Christians to think about during the Jubilee works of mercy and the right spirit. The inclination at this particular time over the works of mercy, according to the intention of the Pope has become a way of awakening our conscience, often dormant, and also allow for deeper entrance into the heart of the Gospel, to know whether we live as His disciples or not.

In making this request, the Holy Father should rethink and rediscover the works of mercy and against the spirit of the catechetical their place in the preaching and catechetical active forms filling these works of mercy, taken and inspired by school religion classes and parish catechesis. For this purpose, will be examined today in force catechetical documents, program materials catechesis in Poland and selected aids for the teaching of religion, namely text books, work sheets, etc. Used during the various stages of education.

Keywords: corporal and spiritual works of mercy, catechesis, catechetical documents. Słowa kluczowe: uczynki miłosierdzia co do ciała, co do duszy, katecheza, dokumenty katechetyczne. 